\title{
Thermococcus guaymasensis sp. nov. and Thermococcus aggregans sp. nov., two novel thermophilic archaea isolated from the Guaymas Basin hydrothermal vent site
}

\author{
Francesco Canganella, ${ }^{1}$ William J. Jones, ${ }^{2}$ Agata Gambacorta ${ }^{3}$ \\ and Garabed Antranikian ${ }^{4}$
}

Author for correspondence: Francesco Canganella. Tel: +39 0761 357282. Fax: + 390761357242.

e-mail: canganel $\alpha$ unitus.it

\footnotetext{
1 Department of Agrobiology and Agrochemistry, University of Tuscia, via C. de Lellis, 01100 Viterbo, Italy

2 Ecosystem Research Division, US Environmental Protection Agency, Athens, GA, USA

${ }^{3}$ CNR, Institute for the Chemistry of Interesting Biological Molecules (ICMIB), Arco Felice (Na), Italy

4 Department of Biotechnology I, Technical University of Hamburg, Germany
}

\begin{abstract}
Thermococcus strains TYS ${ }^{\top}$ and $\mathrm{TY}^{\top}$ isolated from the Guaymas Basin hydrothermal vent site and previously described were compared by DNA-DNA hybridization analysis with the closest Thermococcus species in terms of physiology and nutritional aspects. On the basis of the new data and taking into consideration the molecular, physiological and morphological traits published previously, it is proposed that strains TY' and TYS ${ }^{\top}$ should be classified as new species named Thermococcus aggregans sp. nov. and Thermococcus guaymasensis sp. nov., respectively. The type strain of $T$. aggregans is strain TY' $^{\top}$ (= DSM 10597') and the type strain of $T$. guaymasensis is strain TYS (= DSM 11113').
\end{abstract}

Keywords: Thermococcus, archaea, hydrothermal vents

\section{INTRODUCTION}

During the past 3 years, six additional species belonging to the genus Thermococcus have been described. Presently, 10 species represent this taxonomic group: Thermococcus celer (Zillig et al., 1983), 'Thermococcus litoralis' (Neuner et al., 1990), Thermococcus stetteri (Miroshnichenko et al., 1989), Thermococcus profundus (Kobayashi et al., 1994), Thermococcus peptonophilus (Gonzalez et al., 1995), Thermococcus chitonophagus (Huber et al., 1995), Thermococcus alcaliphilus (Keller et al., 1995), Thermococcus fumicolans (Godfroy et al., 1996), Thermococcus hydrothermalis (Godfroy et al., 1997) and 'Thermococcus zilligii' (Ronimus et al., 1997). All species are organotrophic, thermophilic anaerobes growing preferentially on proteinaceous compounds and utilizing carbohydrates as carbon sources rarely. Elemental sulphur considerably stimulates growth with the concomitant formation of $\mathrm{H}_{2} \mathrm{~S}$. Typical optima temperatures range

Abbreviation: TOR, temperature of renaturation

The EMBL accession numbers for the partial 165 rDNA sequences of strains TY' ${ }^{\top}$ and TYS $^{\top}$ are Y08384 and Y08385, respectively. from 85 to $88^{\circ} \mathrm{C}\left(75^{\circ} \mathrm{C}\right.$ for $T$. stetteri) and the $\mathrm{G}+\mathrm{C}$ content ranges approximately between 42 and $57 \mathrm{~mol} \%$, except for T. litoralis ( $38 \mathrm{~mol} \%$ ). According to the most recent investigations on the microbiology of hydrothermal vent sites, Thermococcus species appear to be present in significant numbers in these ecosystems (Antoine et al., 1995; Marteinsson et al., 1995).

Two novel deep-sea Thermococcus strains TYS $^{\mathrm{T}}$ and $\mathrm{TY}^{\mathrm{T}}$ ) previously isolated from the Guaymas Basin (Gulf of California) and extensively described (Canganella \& Jones, 1994a; Canganella et al., 1997) showed a relatively high similarity of $16 \mathrm{~S}$ rDNA sequences with other Thermococcus species but exhibited some different physiological properties (Canganella et al., 1997). Compared with the most recently described $T$. hydrothermalis and $T$. fumicolans, our strains are able to grow on starch, there is no absolute requirement for elemental sulphur, and they are more sensitive to $\mathrm{NaCl}$ concentrations higher than $5.0 \%$ $(\mathrm{w} / \mathrm{v})$. DNA-DNA hybridization experiments were necessary to determine the taxonomic standing of these two strains. Based on the results of these analyses, both strains were found to represent new species of 
Thermococcus, and their complete taxonomic description is reported in this paper.

\section{METHODS}

Source of micro-organisms. Strains $\mathrm{TYS}^{\mathrm{T}}$ and $\mathrm{TY}^{\mathrm{T}}$ were isolated from sediments collected at the Guaymas Basin hydrothermal vent site $(2000 \mathrm{~m}$ depth) in the Gulf of California. On the basis of nutritional, physiological and molecular features, they were previously described as Thermococcus species by Canganella \& Jones (1994a, b) and Canganella et al. (1997).

T. celer, 'T. litoralis', T. stetteri and T. profundus strains were obtained from DSMZ, Braunschweig, Germany (see Table 1). T. peptonophilus strain OG-1 $1^{\mathrm{T}}\left(=\mathrm{JCM} 9653^{\mathrm{T}}\right.$ ) was kindly provided by Chiaki Kato (JAMSTEC, Yokosuka, Japan) and T. hydrothermalis and T. fumicolans were a gift from Anne Godfroy (IFREMER, Plouzane', France).

Growth conditions. The two novel Thermococcus strains as well as the reference micro-organisms were grown on a mineral medium containing the following constituents per litre of distilled water: $0.33 \mathrm{~g} \mathrm{KCl} ; 2.7 \mathrm{~g} \mathrm{MgCl} .2 \mathrm{H}_{2} \mathrm{O} ; 3.4 \mathrm{~g}$ $\mathrm{MgSO}_{4} .7 \mathrm{H}_{2} \mathrm{O} ; 0.25 \mathrm{~g} \mathrm{NH}_{4} \mathrm{Cl} ; 0 \cdot 14 \mathrm{~g} \mathrm{CaCl}_{2} .2 \mathrm{H}_{2} \mathrm{O} ; 0 \cdot 14 \mathrm{~g}$ $\mathrm{K}_{2} \mathrm{HPO}_{4} ; 0.01 \mathrm{mg} \mathrm{Na} \mathrm{SeO}_{3} ; 0.01 \mathrm{mg} \mathrm{NiCl}{ }_{2} .6 \mathrm{H}_{2} \mathrm{O} ; 1.0 \mathrm{~g}$ $\mathrm{NaHCO}_{3} ; 18.0 \mathrm{~g} \mathrm{NaCl} ; 0.001 \mathrm{~g}$ resazurin; $0.5 \mathrm{~g}$ cysteine. $\mathrm{HCl} . \mathrm{H}_{2} \mathrm{O} ; 0.5 \mathrm{~g} \mathrm{Na} \mathrm{S}_{2} .9 \mathrm{H}_{2} \mathrm{O}$. The medium also contained Bacto-yeast extract $\left(0 \cdot 2 \mathrm{~g} \mathrm{l}^{-1}\right)$ and $10 \mathrm{ml} \mathrm{l}^{-1}$ each of trace metal and vitamin solutions (Balch et al., 1979).

Anaerobic techniques used to prepare and dispense the medium, the enrichment experiments, isolation procedures, as well as the physiological characterization of the new isolates have been described elsewhere (Canganella \& Jones, 1994a, b).

Phylogenetic analysis. DNA of harvested cells was extracted according to the procedure of Marmur (1961), digested to nucleosides, and the $\mathrm{G}+\mathrm{C}$ content was determined after nucleoside analysis by HPLC as described by Mesbah et al. (1989).

Genomic DNA extraction, PCR-mediated amplification of the $16 \mathrm{~S}$ rDNA and purification of PCR products was carried out as described previously (Barns et al., 1994; Rainey et al., 1992; Rainey \& Stackebrandt, 1993).

The 16S rDNA sequence was manually aligned against representative sequences of members of the domain Archaea. The following sequences from the EMBL database were analysed: M21529 (T. celer), Z75240 (T. stetteri), D37982 (T. peptonophilus), Z70252 ('T. litoralis'), Z70244 (T. hydrothermalis), Z70250 (T. fumicolans), Z75233 (T. profundus), X99570 (T. chitonophagus) and U20163 (P. furiosus). Pairwise evolutionary distances were computed using the correction factor of Jukes \& Cantor (1969). The least-squares distance method of De Soete (1983) was used in the construction of the phylogenetic dendrogram from distance matrices.

DNA isolation and hybridization. DNA was isolated by column chromatography using hydroxyapatite according to the procedure of Cashion et al. (1977).

DNA-DNA hybridization was performed according to the methods of De Ley et al. (1970) using a Gilford System 2600 spectrophotometer equipped with a Gilford 2527-R thermoprogrammer and plotter.
The DNA concentration was $45 \mu \mathrm{g} \mathrm{ml}^{-1}$. Owing to the high $\mathrm{G}+\mathrm{C}$ content of Thermococcus DNA (mean value of $50 \mathrm{~mol} \%$ ), $20 \%(\mathrm{v} / \mathrm{v})$ DMSO was added to $2.5 \times \mathrm{SSC}$ to depress the DNA melting point $\left(T_{m}\right)$ (Escara \& Hutton, 1980). The resulting buffer was $2 \times \mathrm{SSC}+20 \% \mathrm{DMSO}$. The mean $T_{\mathrm{m}}$ was determined from the DNA melting curves and the optimal temperature of renaturation (TOR) was calculated as $T_{\mathrm{m}}+25$.

Renaturation rates were calculated by regression analysis between 10 and $30 \mathrm{~min}$ after the reaction start using the computer program TRANSFER.BAS (Jahnke, 1992).

\section{RESULTS AND DISCUSSION}

\section{Morphology of Thermococcus strains TYS ${ }^{\top}$ and TY ${ }^{\top}$}

The morphological features of isolates TYS ${ }^{\mathrm{T}}$ and TY ${ }^{\mathrm{T}}$ have been reported previously (Canganella \& Jones, 1994a; Canganella et al., 1997). Under light microscopy, cells of $\mathrm{TYS}^{\mathrm{T}}$ and $\mathrm{TY}^{\mathrm{T}}$ usually appear as irregular cocci with a variable width of $0.5-3.0 \mu \mathrm{m}$. Strain TYS ${ }^{\mathrm{T}}$ is similar to other Thermococcales species in that a dark granule often forms on the outer cell surface. Strain TYS ${ }^{\mathrm{T}}$ usually exists as single cells, whereas strain $\mathrm{TY}^{\mathrm{T}}$ typically forms cell aggregates up to $50-100$ cells under optimal growth conditions. Both strains are non-motile.

\section{Nutritional requirements}

Strains TYS ${ }^{\mathrm{T}}$ and $\mathrm{TY}^{\mathrm{T}}$ grew chemo-organotrophically on complex substrates, e.g. yeast extract, trypticase, casein, starch, dextrose and maltose. In the presence of elemental sulphur, higher growth yields were observed with proteinaceous compounds, accompanied by $\mathrm{H}_{2} \mathrm{~S}$ production (Canganella \& Jones, 1994a). No growth was detected in medium supplemented with chitin, organic acids (formate, acetate, propionate, butyrate; $0.5 \%, \mathrm{w} / \mathrm{v}$ ), alcohols (methanol, ethanol, propanol; $0.5 \%, \mathrm{v} / \mathrm{v})$, or Difco Casamino acids $(0.4 \%, \mathrm{w} / \mathrm{v})$ as primary carbon sources (Canganella \& Jones, 1994a).

\section{Phylogenetic analysis and DNA hybridization}

The $\mathrm{G}+\mathrm{C}$ content of DNA extracted from Thermococcus isolates $\mathrm{TY}^{\mathrm{T}}$ and $\mathrm{TYS}^{\mathrm{T}}$ was 42.0 and $46.0 \mathrm{~mol} \%$, respectively.

The nearly complete sequences consisting of 1301 bases of the amplified 16S rDNA of isolates TY ${ }^{\mathrm{T}}$ and TYS $^{\mathrm{T}}$ were previously determined. The sequences of both isolates were therefore aligned and compared with all the available $16 \mathrm{~S}$ rDNA sequences of Thermococcus species, including Pyrococcus furiosus. On the basis of these data, the $16 \mathrm{~S}$ rDNA sequence of strain $\mathrm{TY}^{\mathrm{T}}$ showed a similarity of $98.4 \%$ with strain $\mathrm{TYS}^{\mathrm{T}}$, $96.7 \%$ with $T$. chitinophagus, $97.7 \%$ with $T$. hydrothermalis, $97.0 \%$ with $T$. fumicolans and $93.9 \%$ with $P$. furiosus. The $16 \mathrm{~S}$ rDNA sequence of strain TYS ${ }^{\mathrm{T}}$ showed a similarity of $96.6 \%$ with $T$. chitinophagus, $98.4 \%$ with $T$. hydrothermalis and $96.0 \%$ with $T$. 


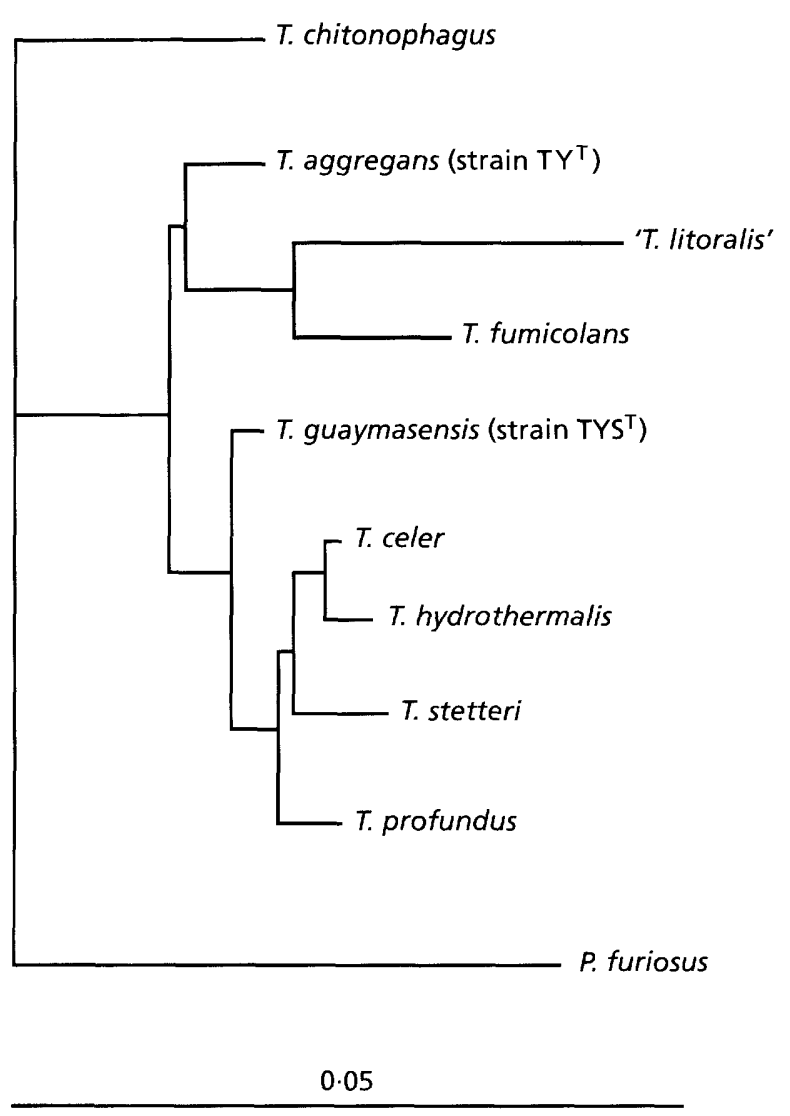

Fig. 1. Unrooted phylogenetic tree indicating the phylogenetic position of $T$. guaymasensis and $T$. aggregans compared with other Thermococcus species and $P$. furiosus.

fumicolans. The phylogenetic tree constructed from all similarity data is shown in Fig. 1.

Thermococcus strains $\mathrm{TYS}^{\mathrm{T}}$ and $\mathrm{TY}^{\mathrm{T}}$ are distinct species as indicated by a DNA hybridization value of $41 \cdot 2 \%$ (Table 1 ). They also exhibit DNA hybridization values less than $70 \%$ with the other Thermococcus species, indicating that they are new and distinct species in accordance with the recommendations of the Committee on reconciliation of approaches to bac- terial systematics (Wayne et al., 1987). Strains TYS and $\mathrm{TY}^{\mathrm{T}}$ are named Thermococcus guaymasensis sp. nov. and Thermococcus aggregans sp. nov., respectively. T. alcaliphilus was not included in this analysis because its primary physiological feature (optimal growth at elevated $\mathrm{pH}$ ) represents a unique taxonomical trait; moreover, its $16 \mathrm{~S}$ rDNA sequence is not available on GenBank. ' $T$. zilligii' was also not included in the present work because its isolation source (terrestrial freshwater hot pool), its inability to grow at $\mathrm{NaCl}$ concentrations higher than $1.2 \%$ (w/v) and its unusual membrane lipid composition clearly differentiate it from the other Thermococcus species.

\section{Description of Thermococcus aggregans sp. nov.}

Thermococcus aggregans (ag'gre.gans. L. v. aggregare to stick together, to aggregate; L. pres. part. aggregans assembling, aggregating).

Coccoid archaeon with cell diameters of $1 \cdot 0-1 \cdot 5 \mu \mathrm{m}$. Cells are Gram-positive, non-motile and occur as single cells, diploid forms or (particularly when cultivated on yeast extract/tryptone plus sulphur) aggregates of many cells (up to 50). Colonies are circular, convex and pale-grey in colour, and colony diameters range from 0.5 to $1.0 \mathrm{~mm}$ after $48-72 \mathrm{~h}$ incubation at $70^{\circ} \mathrm{C}$ under strictly anoxic conditions. Chemo-organotrophic and strictly anaerobic. Utilizes preferably proteinaceous substrates such as yeast extract and trypticase in the presence of $0.5-1.0 \%$ $(\mathrm{w} / \mathrm{v})$ elemental sulphur. Casein, dextrose, maltose and starch are also utilized. The end products of metabolism on medium containing yeast extract plus tryptone and sulphur are acetate, propionate, isobutyrate, isovalerate, $\mathrm{CO}_{2}$ and $\mathrm{H}_{2} \mathrm{~S}$, whereas, after growth on dextrose or maltose plus sulphur, only acetate, $\mathrm{CO}_{2}$ and $\mathrm{H}_{2} \mathrm{~S}$ are formed. The $\mathrm{pH}$ range for growth is $5 \cdot 6-7 \cdot 9$; the optimum $\mathrm{pH}$ is $7 \cdot 0$. Grows between 60 and $94{ }^{\circ} \mathrm{C}$, with no growth occurring at $95^{\circ} \mathrm{C}$. The optimum temperature is $88^{\circ} \mathrm{C}$. The $\mathrm{NaCl}$ range for growth is $1.0-3.0 \%(\mathrm{w} / \mathrm{v})$ with the optimum at $2.5 \%$. The $\mathrm{G}+\mathrm{C}$ content of the DNA is $42.0 \mathrm{~mol} \%$. Lipids are mainly represented by one phospholipid

Table 1. DNA hybridization (\%) between $T$. guaymasensis strain TYS $\mathrm{S}^{\top}, T$. aggregans strain $\mathrm{TY}^{\top}$ and other $T$ hermococcus species

\begin{tabular}{|c|c|c|c|c|c|c|c|c|c|}
\hline Strain & 1 & 2 & 2 & 4 & 5 & 6 & 7 & 8 & 9 \\
\hline $1 T$.gua!masensis (DSM 11113 & 100 & & & & & & & & \\
\hline 2 T. aggregans (DSM 10597 $)$ & $42 \cdot 1$ & 100 & & & & & & & \\
\hline $3 T$. celer $\left(\mathrm{DSM} 2476^{\mathrm{T}}\right)$ & $44 \cdot 4$ & $33 \cdot 9$ & 100 & & & & & & \\
\hline 4 ' $T$. litoralis' (DSM 5474) & $37 \cdot 1$ & $52 \cdot 4$ & $38 \cdot 2$ & 100 & & & & & \\
\hline $5 T$ stetteri (DSM 5262 $)$ & $48 \cdot 7$ & $41 \cdot 5$ & $44 \cdot 9$ & $39 \cdot 9$ & 100 & & & & \\
\hline $6 T$. peptonophilus (JCM 9653') & $48 \cdot 3$ & $31 \cdot 1$ & $49 \cdot 5$ & $33 \cdot 9$ & $47 \cdot 3$ & 100 & & & \\
\hline $7 T$. profundus (DT $5432^{\mathrm{T}}$ ) & $45 \cdot 9$ & $36 \cdot 8$ & $48 \cdot 4$ & $32 \cdot 7$ & $46 \cdot 8$ & $50 \cdot 7$ & 100 & & \\
\hline 8 T. fumicolans (CIP $104680^{\mathrm{T}}$ ) & $50 \cdot 5$ & $55 \cdot 6$ & $49 \cdot 9$ & $40 \cdot 9$ & $49 \cdot 2$ & $59 \cdot 9$ & $44 \cdot 8$ & 100 & \\
\hline 9 T. hydrothermalis (CNCMI 1319 $)$ & $51 \cdot 6$ & $43 \cdot 4$ & $53 \cdot 9$ & $39 \cdot 8$ & $39 \cdot 3$ & $43 \cdot 6$ & $40 \cdot 3$ & $57 \cdot 2$ & 100 \\
\hline
\end{tabular}


and some minor components; core lipids are characteristically archaeol and caldarchaeol compounds in equal amounts. Isolated from marine sediments at the Guaymas Basin hydrothermal vent site (2000 $\mathrm{m}$ depth) in the Gulf of California. Type strain $\mathrm{TY}^{\mathrm{T}}$ has been deposited in the DSMZ -German Collection of Microorganisms and Cell Cultures, Braunschweig, Germany, as strain DSM $10597^{\mathrm{T}}$ and in the Japanese Collection of Microorganisms as JCM $10137^{\mathrm{T}}$.

\section{Description of Thermococcus guaymasensis sp. nov.}

Thermococcus guaymasensis (gua.i.masi'ensis L. gen. n. guaymasensis named after the Guaymas Basin, the name of the deep-sea site where the species was isolated).

Coccoid archaeon with cell diameters of $1 \cdot 0-3 \cdot 0 \mu \mathrm{m}$. Cells are Gram-positive, non-motile and occur mainly as single cells, but also as diploid forms. Colonies are circular, convex and pale grey in colour, and colony diameters range from 0.5 to $1.0 \mathrm{~mm}$ after $48-72 \mathrm{~h}$ incubation at $70{ }^{\circ} \mathrm{C}$ under strictly anoxic conditions. Chemo-organotrophic and strictly anaerobic. Utilizes preferably proteinaceous substrates such as yeast extract and trypticase in the presence of $0.5-1.0 \%$ (w/v) elemental sulphur. Casein, dextrose, maltose and starch are also utilized. The end products of metabolism on medium containing yeast extract plus trypticase and sulphur are acetate, propionate, isobutyrate, isovalerate, $\mathrm{CO}_{2}$ and $\mathrm{H}_{2} \mathrm{~S}$, whereas, after growth on dextrose or maltose plus sulphur, only acetate, $\mathrm{CO}_{2}$ and $\mathrm{H}_{2} \mathrm{~S}$ are formed. The $\mathrm{pH}$ range for growth is $5 \cdot 6-8 \cdot 1$, with the optimum at $7 \cdot 2$. Grows between 56 and $90^{\circ} \mathrm{C}$, with no growth occurring at $95^{\circ} \mathrm{C}$. The optimum temperature for growth is $88^{\circ} \mathrm{C}$. The $\mathrm{NaCl}$ range for growth is $1.0-5.0 \%(\mathrm{w} / \mathrm{v})$, with the optimum at $3.0 \%$. The $\mathrm{G}+\mathrm{C}$ content of the DNA is $46.0 \mathrm{~mol} \%$. Lipids are mainly represented by one phospholipid and some minor components; core lipids are characteristically archaeol and caldarchaeol compounds in equal amounts with traces of tricyclized caldarchaeol. Isolated from marine sediments at the Guaymas Basin hydrothermal vent site ( $2000 \mathrm{~m}$ depth) in the Gulf of California. Type strain TYS ${ }^{\mathrm{T}}$ has been deposited in the DSMZ-German Collection of Microorganisms and Cell cultures, Braunschweig, Germany, as strain DSM $11113^{\mathrm{T}}$ and in the Japan Collection of Microorganisms as JCM $10136^{\mathrm{T}}$.

\section{ACKNOWLEDGEMENTS}

We thank Jutta Burghardt and Cathrin Spröer of DSMZ for DNA hybridization and 16S rDNA analyses, respectively. We also thank Eduardo Pagnotta of ICMIB (Arco Felice, Italy) for the lipid analyses. We are also grateful to J. Wiegel for revising the manuscript. This work was supported by EC grant on 'Extremophiles as Cell Factories', ERBBIO4CT960488 to G. Antranikian and ' $60 \%$ ' and ' $40 \%$ ' grants from the Italian Ministry of University and Scientific Research to F. Canganella.

\section{REFERENCES}

Antoine, E., Guezennec, G., Meunier, J. R., Lesongeur, F. \& Barbier, G. (1995). Isolation and characterization of extremely thermophilic archaebacteria related to the genus Thermococcus from deep-sea hydrothermal Guaymas basin. Curr Microbiol 31, 186-192.

Balch, W. E., Fox, G. E., Magrum, L. J., Woese, C. R. \& Wolfe, W. S. (1979). Methanogens: re-evaluation of a unique biological group. Microbiol Rev 43, 260-296.

Barns, S. M., Fundyga, R. E., Jeffries, M. W. \& Pace, N. R. (1994). Remarkable archaeal diversity in a Yellowstone National Park hot spring environment. Proc Natl Acad Sci USA 91, 1609-1613.

Canganella, F. \& Jones, J. W. (1994a). Microbial characterization of thermophilic archaea isolated from the Guaymas Basin hydrothermal vent. Curr Microbiol 28, 299-306.

Canganella, F. \& Jones, J. W. (1994b). Fermentation studies with thermophilic archaea in pure culture and in syntrophy with a thermophilic methanogen. Curr Microbiol 28, 293-298.

Canganella, F., Jones, J. W., Gambacorta, A. \& Antranikian, G. (1997). Biochemical and phylogenetic characterization of two novel deep-sea Thermococcus isolates with potentially biotechnological applications. Arch Microbiol 167, 233-238.

Cashion, P., Holder-Franklin, M. A., McCully, J. \& Franklin, M. (1977). A rapid method for the base ratio determination of bacterial DNA. Anal Biochem 81, 461-466.

De Ley, J., Cattoir, H. \& Reynaerts, A. (1970). The quantitative measurement of DNA hybridization from renaturation rates. Eur J Biochem 12, 133-142.

De Soete, G. (1983). A least squares algorithm for fitting additive trees to proximity data. Psychometrika 48, 621-626.

Escara, J. F. \& Hutton, J. R. (1980). Thermal stability and renaturation of DNA in dimethylsulphoxide solutions: acceleration of renaturation rate. Biopolymers 19, 1315-1327.

Godfroy, A., Meunier, J.-R., Guezennec, J., Lesongeur, F., Raguénès, G., Rimbault, A. \& Barbier, G. (1996). Thermococcus fumicolans sp. nov., a new hyperthermophilic archaeon isolated from a deep-sea hydrothermal vent in the north Fiji basin. Int $J$ Syst Bacteriol 46, 1113-1119.

Godfroy, A., Lesongeur, F., Raguénès, G., Quérellou, J., Antoine, E., Meunier, J.-R., Guezennec, J. \& Barbier, G. (1997). Thermococcus hydrothermalis sp. nov., a new hyperthermophilic archaeon isolated from a deep-sea hydrothermal vent. Int $J$ Sist Bacteriol 47, 622-626.

Gonzalez, J. M., Kato, C. \& Horikoshi, K. (1995). Thermococcus peptonophilus sp. nov., a fast-growing, extremely thermophilic archaebacterium isolated from deep-sea hydrothermal vents. Arch Microbiol 164, 159-164.

Huber, R, Stohr, J., Hohenhaus, S., Rachel, R., Burggraf, S., Jannasch, H. \& Stetter, K. O. (1995). Thermococcus chitonophagus sp. nov., a novel, chitin-degrading, hyperthermophilic archaeum from a deep-sea hydrothermal vent environment. Arch Microbiol 164, 255-264.

Jahnke, K.-D. (1992). BASIC computer program for evaluation of spectroscopic DNA renaturation data from Gilford $S_{y}:$ 2600 spectrophotometer on a PC/XT/AT type personal computer. $J$ Microbiol Methods 15, 61-73.

Jukes, T. H. \& Cantor, C. R. (1969). Evolution of protein molecules. In Mammalian protein metabolism, pp. 21-132. Edited by H. N. Munro. New York: Academic Press.

Keller, M., Braun, F.-J., Dirmeier, R., Hafenbradl, D., Burggraf, S., 
Rachel, R. \& Stetter, K. O. (1995). Thermococcus alcaliphilus sp. nov., a new hyperthermophilic archaeum growing on polysulfide at alkaline pH. Arch Microbiol 164, 390-395.

Kobayashi, T., Kwak, Y. S., Akiba, T., Kudo, T. \& Horikoshi, K. (1994). Thermococcus profundus sp. nov., a new hyperthermophilic archaeon isolated from a deep-sea hydrothermal vent. Syst Appl Microbiol 17, 232-236.

Marmur, J. (1961). A procedure for the isolation of deoxyribonucleic acid from microorganisms. $J$ Mol Biol 3, 208-218.

Marteinsson, V. T., Watrin, L., Prieur, D., Caprais, J. C., Raguénès, G. \& Erauso, G. (1995). Phenotypic characterization, DNA similarities. and protein profiles of twenty sulfur-metabolizing hyperthermophilic anaerobic archaea isolated from hydrothermal vents in the southwestern pacific ocean. Int J Syst Bacteriol 45, 623-632.

Miroshnichenko, M. L., Bonch-Osmolovskaya, E. A., Neuner, A., Kostrikina, N. A., Chernych, N. A. \& Alekseev, V. A. (1989). Thermococ'us stetteri sp. nov., a new extremely thermophilic marine archaebacteria. Syst Appl Microbiol 12, 257-262.

Mesbah, M., Premachadran, U. \& Whitman, W. B. (1989). Precise measurement of the $\mathrm{G}+\mathrm{C}$ content of deoxyribonucleic acid by high performance liquid chromatography. Int $J$ Syst Bacteriol $39,159-167$.
Neuner, A., Jannasch, H. W., Belkin, S. \& Stetter, K. O. (1990). Thermococcus litoralis sp. nov., a new species of extremely thermophilic marine archaebacteria. Arch Microbiol 153, 205-207.

Rainey, F. A., Dorsch, M., Morgan, H. M. \& Stackebrandt, E. (1992). 16S rDNA analysis of Spirochaeta thermophila: its phylogenetic position and implications for the systematics of the order Spirochaetales. Syst Appl Microbiol 15, 197-202.

Rainey, F. A. \& Stackebrandt, E. (1993). 16S rDNA analysis reveals phylogenetic diversity among the polysaccharolytic clostridia. FEMS Microbiol Lett 113, 125-128.

Ronimus, R. S., Reysenbach, A.-L., Musgrave, D. R. \& Morgan, H. W. (1997). The phylogenetic position of the Thermococcus isolate AN1 based on $16 \mathrm{~S}$ rRNA gene sequence analysis: a proposal that AN1 represents a new species, Thermococcus zilligii sp. nov. Arch Microbiol 168, 245-248.

Wayne, L. G., Brenner, D. J., Colwell, R. R. \& 9 other authors (1987). International Committee on Systematic Bacteriology. Report of the ad hoc committee on reconciliation of approaches to bacterial systematics. Int J Syst Bacteriol 37, 463-464.

Zillig, W., Holz, I., Janekovic, D., Schafer, W. \& Reiter, W. D. (1983). The archaebacterium Thermococcus celer represents a novel genus within the thermophilic branch of the archaebacteria. Syst Appl Microbiol 4, 88-94. 
